\title{
APPLICATION OF COMPUTER IN THE ADMINISTRATION OF COLLEGES OF EDUCATION IN NIGERIA
}

\section{S. S. GANI}

\begin{abstract}
There is really no doubt that, Computer Education and utilization are very essential not only in educational institutions but in all aspects of modern societies. This paper discusses the usage of computer in Nigerian Colleges of Education which includes checking the in and out of library materials, keeping staff confidential records as well as keeping students examination results more accurately. The paper also highlights the benefits of computer usage in Nigerian Colleges of Education such as facilitating students learning and providing opportunities for students especially those specializing in Computer Education to become system analysts, computer operators, business center managers, software engineers and hardware engineers in their future undertaking. However, the limitation with computer usage in Nigerian Colleges of Education is that students find it difficult to understand lessons in Computer Education because they lack the basic knowledge of computer. Also students may have the tendency to write assignments by simply downloading relevant or irrelevant information from the net. As a result of these limitations, the writer recommends that the federal and state Ministries of Education should employ well trained personnel that can manage the computer sets provided to the colleges effectively. Also, staff in Colleges of Education should be encouraged to utilize the computer in carrying out some of their responsibilities.
\end{abstract}

\section{Introduction}

Modern societies are characterized by a rapid development in science and technology. In education, the complexity and volume of knowledge has continued to grow immeasurably, as a result of which, it is necessary to equip the rising generation with an ever-increasing amount of knowledge. The thought of allocating more time for classroom instruction may not produce the desired results because students today do not require this to learn and develop. In the past, a teacher was expected to be vast in book knowledge and be able to impact it to the students. In addition, a teacher today is expected to know the students well, be conversant with the complexity of modern societies, as well as integrate all knowledge that will enhance the teaching and learning processes. On the basis of this background, it is important to increase the effectiveness of instruction and the general administration of educational institutions such as Colleges of Education in Nigeria. This can be achieved by using proper scientific theories and technological means of automating and processing information which demands the application of computer.

\section{A Brief History of the Computer}

The first electronic digital computer known as ENIAC was developed by the University of Pennsylvania in 1946 as an electronic calculator to solve complex mathematical formulae ( Harrison, 1983). Today however, the computer is used to perform numerical computations, inventory control, point of sale transactions, manufacturing operations, word processing and many other activities. Of all the uses of computers, their role in education has generated the greatest controversy. One of the first educational applications was designed by Patrick Suppes in the Mid 1960s. 
A series of programmes to drill arithmetic facts for elementary school children was developed and tested (Harrison,1983). This modest beginning touched off the debate about the proper role of the computer in educational institutions, and from all indications, it is certain that the micro computer will be a permanent fixture in the classroom of advanced societies.

In Nigeria, the history of Computer Education reveals that, computer was used to process the figures of the 1963 population census (Ramalan, 2003). This exercise was conducted by non Nigerians because at that time, only a few Nigerians could operate the computer. As a result of this situation, the world trade corporation and the University of Ibadan agreed to advance the use of modern data processing methods in Africa through training programme of several types and so an African Education centre was established to train Nigerians and other Africans in Computer Education (Nwakolo, 1995).

\section{Clarification of Basic concepts}

For a better understanding, the key concepts used in this paper are hereby defined.

Computer: the computer is an electronic device that accepts input called data, processes the input under the controlled guidance of a computer programme and gives out an output called information. Similarly, Nwakolo (1995) defines computer as a fast and accurate electronic device that is designed with the capability to automatically accept input data, process the data and produce results, under the influence or direction of a stored programme of instruction. Computer Education therefore, is the education that centers on the general understanding, operation and application of the computer.

Administration: The word administration is commonly used to mean to run, to direct, to control or to manage the affairs of an organization. Although such definitions are in order, they are simply concerned with specific features of administration. Administration refers to the total process through which appropriate human and material resources are made available and used effectively for the accomplishment of organizational objectives. In educational institutions such as Colleges of Education, all activities are carried out towards the accomplishment of the goals of teaching and learning. The Provost as the administrative head works cooperatively with other members of staff and by so doing, he or she is able to plan, organize, co-ordinate, control and evaluate all human and material resources of the college in order to achieve the educational objectives designed by the Ministry of Education.

\section{Application of Computer in Colleges of Education}

In modern societies, technologies of different kinds are the answers to success in almost all aspects of life. For instance, nobody can deny the explosion and influence of the micro computer industry over the past two decades. The computer influences the preparation of food at homes or in the canteens, the games children play or even the movies that are watched. The computer is a potential that waits to be tapped to improve the quality of doing things. In line with this, the computer can be used in various ways to help in the administration of educational institutions such as Colleges of Education. 
There are basically two forms of computer usage, that is, as a dispenser of education and as a tool. The application called Computer Aided Instruction or Computer Assisted Instruction (CAI) refers to any of a wide range of educational techniques that rely on a computer to assist in the presentation of learning materials (Ngwu, 2009). The computer in this aspect, presents the problem, the student responds, the computer evaluates the response and the process is repeated. These programmes allow a slow learner to repeat an exercise without embarrassment or ridicule and other learners can practice new concepts to reinforce what is already known. The advantage of this method is that, it allows a student to progress at his or her own pace and lessons can always be repeated to gain mastery or proper understanding.

Another type of Computer Assisted Instruction is the simulation (Onyefulu, 2001). In this method, the computer mimics a real world situation and poses options to the student. The computer then evaluates each decision and determines its effects. The programmes may then prompt the user with another question. To successfully take advantage of this method, the student must develop logical reasoning. In line with this, Achimugu (2009) adds that, the use of communication systems such as the computer, opens new possibilities for learning, and allows learning in schools and colleges to integrate with learning elsewhere.

Although these methods affect the student's understanding of the instructions presented, the CAI does not replace, but only supplements the teacher in the way films, typewriter or library do. However, for more advance students, some technical subjects may be taught by the computer alone, but even then, this is no substitute for the classroom teaching because computerized instruction can only offer limited types of presentation and cannot answer all the students questions. Currently, various computerized aids to learning are being developed in many subjects areas, but like the textbook, they provide only one element of teaching and still require an instructor for a balanced presentation (Shehu, Akumar, Orabuike, \& Mwakodo, 2004).

In Nigeria, national examinations such as the West African Senior School Certificate Examination (WASSCE) and the National Examination Council (NECO), are conducted annually for thousands of secondary School leavers. These examinations are scored, graded and sorted out for admission in to tertiary institutions such as Universities, Polytechnics and Colleges of Education. To ease the problem of time and resources used in doing these, standard answer sheets for objective questions can be prepared and fed into the computer through some reading devices attached to the computers Similarly, to minimize the burden of long queues often experienced during students registration, the large number of students annually admitted into Colleges of Education, can be directed to register online.

In educational institutions such as Colleges of Education, keeping records is not an innovation because teachers have traditionally kept notes of their students academic performances and progress in record books or index cards that may be less accurate and secured than information stored in a well engineered computer system. Apart from students' examination results, the computer can be used to store different types of information such as staff payroll, inventories of school supplies placing order and writing requisitions, drawing checks and other routine tasks relating to budget control. The computer can also be used to store relevant information of staff in the College. For instance, if the college wants to assign teachers to appropriate classes, their educational qualifications and experiences can be accessed easily from the computer. 
In the past, it was possible to do this, but it was such a tedious task for personnel officers in charge of it. In this regard Okwori (2000) stresses that, information stored in computer is preserved for a long time without problems once the computer diskette is kept safely. Abdullahi (2010) adds that, computer networks are increasingly serving as an aid to communication, storage and retrieval of information.

The computer can be used in the college library to assist in checking the in and out of library materials, and to computerize reference guides and periodicals. With this in place, instead of consulting a readers' guide to periodic literature, an individual can simply enter certain information about a particular subject into the computer and it will provide a list of available articles and reference materials on the subject.

The computer can also be used in the guidance and counseling services provided in Colleges of education. For instance, the computer can be used to record and compile large amounts' of data about an individual. After evaluating the data, a counsellor can raise appropriate questions with the counsellee. In the past, it was not possible to find ways of indentifying, collecting and summarizing large amount of data on an individual, which the counsellor may need to work with. Also, students can simply input a number of parameters concerning vocational preferences and the computer prints out a description of jobs or careers that match those parameters. An example of a computer- based guidance system is the interactive guidance and information which was developed by the educational testing service. This system helps secondary school students to make career decisions by checking their own information with more information about occupations This implies that the computer can store information on personal qualities needed for success in any give occupation, the chances that an individual with certain background has of succeeding in the field and the personal and financial benefits the field offers (Shehu et. al., 2004).

The computer can be used to conduct researches. Ngwu (2009) adds that, computers are also used to carry out researches in schools and research institutions in Nigeria. The computer in this regard allows researchers to search for information needed and to analyse the research findings. Many of the earliest recognizable computers were developed and used in the universities of the western world. Since then, the computer has grown in importance as a research tool, so much so that today it is not possible in many subject areas to conduct a research work without access to a computer. As such, Colleges of Education now have a Computer Department Which serves both staff and students by providing training in programming and by meeting the computing needs for undergraduate education for research and administrative purposes.

\section{General Benefits of Computer Utilization in Colleges of Education}

The computer industry is the fastest growing industry in the world and developing countries such as Nigeria can benefit from it in various ways. The most important way is that many employment benefits are accruing from this industry. Students in Colleges of Education whose area of specialization is Computer Education have the advantage of becoming systems analysts, software engineers, hardware engineers, programmers, computer operators, business centre managers and desk top publishing experts in their future endeavours. These opportunities reduce the unemployment problem that has continued to increase among educated youths in Nigeria. 
The computer also facilitates students learning and helps.them to improve upon their academic performances especially in subjects that may not be interesting due to the techniques used or made available for learning. The students can also search for information to carry out assignments or better understanding of topics being taught in the classroom.

The computer helps the College management to plan and make decisions appropriately, and to manage human and material resources effectively. This also reduces the hours used in the process of compiling information to be used by the college management.

The computer assists individual lecturers to store their own personal information which may be needed by the college at anytime. Lecturers can also store students examination results for the courses they teach because such information may be needed anytime.

\section{Limitations of Computer Usage in Colleges of Education}

As with other media and technological innovations, the computer usage in Colleges of Education has some limitations and these include the following:

Computers are expensive to install and maintain especially for the usage of a large number of students admitted for Computer Education in Colleges of Education. This is more so because Nigeria is a developing countries and educational resources in general are not always sufficient.

The maintenance of computer in Colleges of Education can be a problem especially if the systems are subjected to over use or badly used by a large number of Computer Education students. This problem becomes compounded when manpower with technical know how is not available or adequate.

Computer Education is not offered in most public primary and secondary schools. Students admitted for Computer Education in Colleges of Education lack the basic knowledge of computer and this is why such students find it difficult to understand lessons in Computer Education (Ngwu, 2009).

İn Nigeria, peopls: are used to inadequate power supply. In some rural areas, villages have no electricity at all. The computer system cannot function without power supply and this affects the teaching and learning of Computer Education in schools.

Another problem of computer usage in Colleges of Education is the tendency for students to write assignments by simply searching and down loading information from the net without studying its appropriateness to the assignment at hand. This in a way makes some students lazy by believing that assignments can be done by simply copying any information from the net.

\section{Recommendations}

Based on the limitation of computer Utilization highlighted in this paper, the following recommendations are offered:

1. The Federal Government of Nigeria through the Federal Ministry of Education should provide all the necessary financial assistance for the purchase, 
installation and maintenance of micro computers and the relevant software. This will no doubt encourage and enhance the teaching and learning of Computer Education in Colleges of Education in Nigeria.

2. The Federal Ministry of Education should also provide qualified technical manpower which is very essential. The emphasis should not only be limited to computer instructors, but also on personnel that can manage the computer, the storage and retrieval of information systern in the computer. This will minimize constant failure or damage on the computer systems provided to the colleges.

3. The provision of opportunities for staff in Colleges of Education to undertake training in Computer Education is quite encouraging. However, the emphasis should be on the practical aspects and not on the theorical or certificates aspects of the programme.

4. Colleges of Education in Nigeria should organize regular conferences, seminars and workshops on the use of computer for all categories of staff in the colleges. This will improve staff understanding and utilization of the computer.

\section{Conclusion}

The application of computer in Colleges of Education is no doubt very important. The lecturers now know that the computer can store and process information that can be applied in teaching and learning. The computer can be used as a classroom resource, as a calculator, as a means of some real life situation or as a means of producing animated visual aids. To the college management, computers serve as solution to every documentation and provide a means of security for confidential records of staff. The computer also assists the college managers to plan and control human and materials resources provided for the college effectively. The computer also assists students in general not only those offering Computer Education to learn better and improve upon their academic performances.

\section{References}

Abdullahi, I. (2010); Using the Internet to Enrich the Teaching-Learning System. Kaura Namoda Journal of General Education, 11 (1): 2868-2881.

Achimugu, D. H. (2009): the Importance of Information and communication Technologies in Teaching and Learning. Knowledge Review; A Multidisciplinary Journal. A publication of the National Association for the Advancement of Knowledge, 19 (5): 129-135.

Harrison, M. (1983): Computers in Education. Benefit or Bombshell? Antic, 2 (6): 33 36.

Ngwu, O. G. (2009): Repositioning Computer Education: key to Qualitative Learning in Nigeria. Knowledge Review: A Multidisciplinary Journal. A publication of the National Association for the Advancement of knowledge. 19 (5): 57-61.

Nwakolo, K. J. (1995): Computer Appreciation for Beginners. Awka, Nigeria. Futuretech Publishers.

Okwori, R. O. (2000): Towards Effective Dissemination of Technological Information in the Libraries. Zaria Journal of Educational Studies. A Publication of Federal College of Education. Zaria, 4 (1-2): 162-167 
Onyefulu, C. (2001): The Use of Technology in Teaching and Learning. Nigerian Journal of Curriculum and Instruction. A publication of the National Association of Curriculum Theorists. 10 (6): 8-12.

Ramalan, M. M. (2003); Computer Application in Education. Seminar Presentation. Department of Computer Education, Federal College of Education, Zaria.

Shehu, S.; Akumur, D. H.; Orabuike, O. \& Nwakodo, O. B. (2004); Application of computers in educational institutions. Seminar Presentation Computer Training Institute, Zaria. 